\title{
Changes in HIV transmission profile in Arad county
}

\author{
Dana Negru ${ }^{1 *}$, Teodora Olaru², Laura Nicolescu', Mirandolina Prişcă² \\ From The 7th Romanian National HIV/AIDS Congress and The 2nd Central European HIV Forum \\ Sibiu, Romania. 29-31 May 2014
}

Initially HIV infection in Arad County was impacting infant population. Later most of the new cases were adults, but even so trends in recent years are moving in the same way for adults and children, the latter being infected through vertical transmission.

The hypothesis was to determine the relationship between age of cases at diagnosis moment and route of transmission in more than two decades from 1990 till now. We have used data from the medical records of HIV-AIDS department of Arad County Emergency Hospital, from 1990 to 2013 statistical processing with SPSS.14.0 for Windows, MedCalc and Epi Info Analysis.

Of the 437 patients, children and young people 1-19 years were $68 \%$, gender ratio $\mathrm{M} / \mathrm{F}$ being 1.31 . Parenteral route of transmission covered $47 \%$, sexual $22 \%$, vertical $2 \%$, and unknown for $29 \%$ (statistically significant relationship between age at diagnosis and transmission path $\mathrm{p}=0.000$ ). Only 149 patients are monitored $/ 34 \%, 174 / 40 \%$ are out of records and $114 / 26 \%$ died. There are many associated infections like HBV, HCV, TB, CMV, ITS, total $166 / 38 \%$ among total of 437 cases. Relative risk for parenteral transmission was 2.34 in the first decade compared to the second one and reached up to 7.7 for sexual transmission route in the second decade, compared to the first decade.

Pediatric HIV infection versus adult HIV infection rate is changing from 5.53 in the first decade to 0.35 in the second one, risks of sexually transmitted infection becoming dominant for the second decade.

\section{Authors' details \\ ${ }^{1}$ Public Health Department, Arad, Romania. ${ }^{2}$ Arad County Emergency Hospital, Arad, Romania.}

Published: 29 May 2014

${ }^{1}$ Public Health Department, Arad, Romania

Full list of author information is available at the end of the article
doi:10.1186/1471-2334-14-S4-P9

Cite this article as: Negru et al: Changes in HIV transmission profile in

Arad county. BMC Infectious Diseases 2014 14(Suppl 4):P9.
Submit your next manuscript to BioMed Central and take full advantage of:

- Convenient online submission

- Thorough peer review

- No space constraints or color figure charges

- Immediate publication on acceptance

- Inclusion in PubMed, CAS, Scopus and Google Scholar

- Research which is freely available for redistribution

Submit your manuscript at www.biomedcentral.com/submit
() Biomed Central

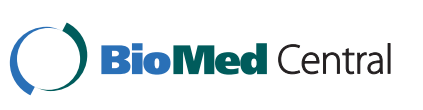

(c) 2014 Negru et al; licensee BioMed Central Ltd. This is an Open Access article distributed under the terms of the Creative Commons Attribution License (http://creativecommons.org/licenses/by/4.0), which permits unrestricted use, distribution, and reproduction in any medium, provided the original work is properly cited. The Creative Commons Public Domain Dedication waiver (http:// creativecommons.org/publicdomain/zero/1.0/) applies to the data made available in this article, unless otherwise stated. 